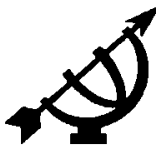

\section{H.F. Verwoerd: Foundational aspects of his thought}

\author{
J.J. Venter \\ Department of Philosophy \\ Potchefstroom University for $\mathrm{CHE}$ \\ POTCHEFSTROOM \\ E-mail: filjjv@puknet.puk.ac.za \\ Abstract
}

\section{H. F. Verwoerd: Foundational aspects of his thought}

This article is an attempt to highlight the foundations of the thought of the influential South African leader, H.F. Verwoerd, as implicitly contained in his published writings. Venwoerd has been characterised as the "architect of apartheid", but this is an exaggeration, since he found the basic principles of apartheid ready-made when he emerged as a leader. From Western tradition Verwoerd inherited a particular respect for rationality, which in his case became a stringent application of the principle of one people ("volk"), one state; conceiving of a people in organic terms reminiscent of the republicanism of Rousseau. In his views on development he appears to have been aligned to the dualistic theories of development, which accorded well with the separation of races. This view was complemented by a belief in inevitable progress reminiscent of $18 \mathrm{th}$ and $19 \mathrm{th}$ century Western tradition, which blinded him to the suffering his belief in apartheid as progress was causing. Education was also conceived of as serving the needs of the ethnic group; a totalitarian approach embedded in the idea of an organic unity of the people.

\section{Introduction}

H.F. Verwoerd became known as the "architect of apartheid" (Kenney, 1980) Whether one accepts this characterisation or not, his way of thinking had enormous practical influence on peoples' lives, since he successively occupied the key positions editor of a party mouthpiece, minister of social welfare, minister of bantu education, and prime minister during his career. A study of his way of thinking supports the understanding of a legacy with which present-day South Africa is struggling - the unravelling of the practical consequences of a philosophy about race and ethnicity which is being blamed for the large-scale oppression of people of colour, the loss of human dignity, widespread poverty, homelessness, illiteracy, crime, etceteras. 
Ethnicity and race have grown into matters of prime importance in the presentday world of mass demographic movements. Homogeneous populations are fast disappearing, and ethnic and racial tensions are surfacing in many countries; even in those that have been very critical of South Africa under the National Party government. A study of the thought of the supposed architect of a political dispensation which was tending in the direction of a civil war between races and ethnic groups, may at least contribute to an understanding of the kind of foundational theses which do not contribute to the realisation of human rights, peace, and development.

Secondly, the study of Verwoerd's way of thinking may contribute to a clarification of Verwoerd's contribution to apartheid thinking, and thus also to a better understanding of the extent of responsibility of others with regard to the system of "separate development". Is the characterisation, "architect of apartheid" fair? "Fair" in the sense that it does not overestimate his original contribution to apartheid thought, and at the same time does not award blame for a way of thinking which was not his alone. I intend to argue that Verwoerd was indebted to Afrikaner and European thought for much of the basis of his thinking - apartheid was not his invention, though he was the one to plan much of the implementation of it.

In the third place the change of the name of the policy from "apartheid" to "separate development" under Verwoerd's leadership was an attempt to bring out an intended aspect of the policy, namely that it was intended as a development policy. It was a development policy in line with the "dualistic" development theories of the time, according to which the disadvantaged section of a dualistic economy would grow by itself once economic growth in the developed section of the economy had been obtained. Since the development problem is still of prime importance, a study of Verwoerd's approach will help clarify the effects of unequal development which has been effected in South Africa, and will contribute to outgrow or review the basis of this approach. It remains important, since late capitalism with its insistence on global competitiveness and the hegemony of the free market, is very similar in structure to the dualistic theories of development.

This article is largely expository. It offers an attempt to clarify the philosophical (in the wider, not the technical, sense of the word) basis of Verwoerd's thought. Three of his recurring basic concepts form the central focus of this analysis: rationality; the ideal of a republic of the people ("volk"); and his views on development.

Verwoerd found his guides in the concepts "understanding" and "faith in God". He continually induced his followers to follow their "understanding" rather than react emotionally to crises. His style is almost as drily rationalist as that of Kant. After his doctoral thesis, Verwoerd published no academic works. His published 
newspaper articles and speeches are simple and not difficult to follow, but present bone-dry logical applications of his basic premises - his popularity clearly did not stem from effective demagoguery. In as far as ideology is said to be "rational manipulation", it may be possible to say that Verwoerd's strict practical application of his principles about ethnicity, race and social life in general, was ideologically-based. Faith and reason remained parallel lines which could not meet

One basic thesis of his thinking, like the idea of an ethnic democratic republic, was part of the Afrikaner's way of thinking at least since the days of the Dutch Batavian Republic at the Cape, which influenced the reception of ideas from the French revolution among Afrikaners for at least two centuries. The idea of an ethnic democratic republic was an invention of the French Revolution, moulded on the form of the ancient Western city state - it was surely not an invention for which Verwoerd has to be either credited or blamed. The eighteenth and nineteenth century moulded this ethnic nationalism in confrontation with British colonialism. Verwoerd worked for this ideal, and almost embodied it in his person. He was the man who realised this supreme good, and this alone goes a long way to explain the Verwoerd adoration in the last years of his reign. In this context he showed himself somewhat of a freethinker: he believed that Afrikaners and English-speaking South Africans could become one people - he used the word "volk" for this unit. Blacks, however, could not join them.

Although widely read, Verwoerd had his academic roots in Mill's positivism this was the methodological source at least of his doctoral thesis in experimental psychology (cf. Verwoerd, 1925:17 ff.). Although he did visit Germany during his formative years as an academic, he did not simply adopt romantic Idealism like so many of his fellow Afrikaner leaders, who studied in Germany in the Weimar era. He tended towards totalitarian social planning on the basis of a few principles (as we shall indicate later), which is reminiscent of the technocratic social engineering tradition related to positivism. In his later years moderate idealistic traits surfaced. He derived his views on history and progress probably from this background of the eighteenth and nineteenth century philosophical spirit of the times.

Like so many Europeans in the 19th and early 20th century, Verwoerd simply believed in the inherent superiority of Western culture. In his younger days, this idea was concentrated in the Afrikaner, but in his later years he came to believe that white people (Afrikaner and English speaking) as a unity had to lead development. His philosophy was in many ways a modern dualistic attempt to do what its smarter name, "separate development", expressed: the pretence of the more developed rubbing off on the less developed through interaction by trade and political links. The less developed, however, could only develop within the boundaries of their ethnic context. In fact, he considered it treason for a person not to be engaged in the upliftment of his/her own ethnic group. 
H.F. Verwoerd: Foundotional aspects of his thought

Part of his views on development was a vision of progress. This was embedded in a typically Western view of history, founded in the eighteenth century "historic turn", in terms of which history itself became ultimate reality, which acquires a human meaning through continued rational Enlightenment, both through science and through rational practice. Verwoerd ascribed a destiny to the Afrikaner, which in the context of his pattern of thought meant more than the stereotypical application of the Calvinist doctrine of predestination to the Afrikaner nation. It rather (also) presupposed the belief in an inherent human teleology in history, which was part and parcel of eighteenth and nineteenth century secular thought.

Verwoerd's line of thought was therefore not divorced from the Western tradition, and also not from Afrikaner tradition (and it is common knowledge that these traditions are linked too). Thus, even a focused discussion of Verwoerd's general philosophy, like the present article, is also a reflection on these traditions, and a reminder of a common responsibility for the outcome.

\section{Rationality}

Asking his followers in the crisis year of 1960 to trust their government - a request reminiscent of Jean-Jacques Rousseau's demand that the citizens trust public reason and obey the general will - Verwoerd (1963:356) promised a fair and rational management of the country and its problems:

We shall not act unfairly in any way. We shall not allow our understanding to let us down. For a leader who has to take care of a people ('volk'), cannot govern, driven by emotions or vengefulness. It is our task in these heavy times, while the heart often wants to speak, to let understanding dominate understanding and faith. Carried by faith in God, the government will not be able to govem unfairly. Faith and understanding does not, however, say that we have to act timidly when greater evils may follow. Power is sometimes the best means to get peace (my translation: Lacking a better English word, I have as far as possible translated "volk" with "people" in the singular - JJV).

The language and style of formulation is almost that of Kant - the suppression of the lower aspects of organic conscious life (emotions and passions), in order to allow reason to dominate. Verwoerd, by means of this kind of discourse, positioned himself squarely within Western rationalist discursive tradition, dating back to at least the eighteenth century, conceiving of human beings in terms of "reason" on the one hand, and "sentiment "emotions", "passions", "instincts", and the "senses" on the other. Rationalists like Daniel Defoe (cf. Roets, 1996:14-22), Jean-Jacques Rousseau (cf. Venter, 1996:124ff.), Kant (cf. Venter, 1991:7ff.), and the Positivists, had "reason" dominating the scene (at least "eschatologically"). During the nineteenth century, and especially in philosophico-literary circles, such as the Romanticism, Realism, Naturalism, and others, more attention was given to the other mentioned "irrational" factors in 
human life. (Irrationalism had its dialectical cradle in the reaction to the eschatological dominance of reason in Enlightenment philosophy). Verwoerd, being a trained psychologist who studied the affective functions in his younger days (cf. Verwoerd, 1925), did realise the importance of the "lower" human functions, but almost like Defoe (in Robinson Crusoe), Rousseau and Kant, he wanted them suppressed for the sake of a clear and future-oriented (progressive or even eschatological) solution of the human problems which faced his generation.

Demonstrating that a rational government is not a weak government, Verwoerd referred to the enormous development which took place over the previous decade of National Party government. He argued that the colour problem had nothing to do with being a monarchy or being a republic, and promised that as long as the National Party remained in power, not oppression, but the preservation of the supreme good (each nation its own land and government), would be cared for. In this regard Verwoerd extended the concept of "a people" to include the English speaking section of the population; he pleaded for the relinquishment of the war between brothers (the English and the Afrikaner whites), through a unification of symbols, so that the whites would become one "volk" with two languages, but with an individual patriotism. Posing the question of whether the intended republic would be a member of the Commonwealth, he (Verwoerd, 1963, 262) stated that self-interest and rationality would be the basis for such a decision: "This is not a question connected with sentiment. I would like us to use especially our understanding here. Everywhere in the world there are states which are grouped together according to their own interest" (my translation - JJV).

To imply that acting according to one's own interest is a good rational approach (omitting the sentiments from the picture), is a very modern conception of the rational. It is a goal-directed rationality which derives from the capitalist economic tradition, but here applied to national interest (cf. Habermas, 1980:81 ff ). This kind of rationality, when defended by the stronger over against the weaker, may practically imply the preservation of privilege, or even the gaining of privilege at the cost of the weaker. In the specific case of membership of the Commonwealth, a silent weaker element in the form of the non-enfranchised citizens of South Africa did exist.

Verwoerd was never very clear on the relationship between faith and reason (or faith and pulitics) - he trusted in God, but did not to take specific Christian beliefs as basis for political action. In the first quote above his thesis seems to be that faith guarantees fair government, but he weakens this position almost immediately by stating that neither understanding nor faith makes for timid government. But, critically, if one too easily believes that a government of believers cannot be unfair, then this may have the consequence of overconfident continuation of a policy supposed to be fair, without actually testing it against 
the tenets of faith regarding justice. Neither here nor elsewhere does Verwoerd give any real content to the supposed link between faith and fair government. In fact, it seems as if strong government and faith mutually support each other without a link of content. According to Verwoerd the support in crises stemming from faith, is also undergirded by a kind of triumphalist support for faith from the side of government policy, in which the triumph of Christianity is linked to white hegemony:

After half a century of co-operation - difficult, at times very difficult - a stage has been reached when both groups as never before are faced with a challenge to bury the past, to let it become the combined history of a unified people ("volk"). Today we are faced with threats for the future of our civilisation, for our prosperity, for the contribution of the white man of Africa to the struggle of the white man of Europe and America to retain his hegemony in the world. Also to make Christianity victorious, sacrifices must be made, and nowhere is Christianity more threatened than in Africa. Sacrifices of sentiment is expected of everybody. There must not only be a union of provinces in South Africa. There must also be a union of hearts (Verwoerd, 1963:377; my translation JJV).

The sentiments to be sacrificed are those of Afrikaners and English-speakers, each for their own heritage (especially that of British monarchy versus republic) All in a row, the hegemony of the white man in Europe and the U.S., in Africa, and the victory of Christianity, are linked with the idea of the unification of Afrikaner and English-speakers for the sake of the republic in spe. In his rationalisation of the ideal of a white republic, developing separate black "states" under white guardianship (the alternative would be a black autocracy which he believed held no future for any group), he asks for sacrifices for a "cause". This appears to be a "volksideal" gone ideological in the sense of claiming allegiance above all else. Individuals may draw their strength from faith, but the ideal has already pushed faith to the periphery. It claims the life of the people: "to sacrifice all rather than lose our freedom"; (p. 378), and it demands a militaristic attitude of following strong leadership (expressed in male sexist language)

We must have the courage of men and be strong. But the will to resistance of a people ('volk') is linked to the kind of leadership which he chooses for himself. If he has the will to resistance, he searches for strong leadership and not weak leadership. If you want to be victorious, you have to be prepared to follow leaders who are not prepared to cave in (Verwoerd, 1963:380; my translation - JJV).

Verwoerd - this is my contention - found in the Christian faith a confirmation of his party's policies, of his leadership - either he did not test his ideals against the tenets of his faith or the Bible, or he was reading the Bible in terms of the tenets of his party. For him it seems to have been fairly simple: God planted the white man in Africa with a destination, and of course, His aims will be fulfilled 
Afrikaners often spoke about their divinely-given destination, without testing their understanding of this destination, and seemingly without allowing for the possibility that God could lose His patience with Afrikaners and decide otherwise. Verwoerd shared in the Afrikaner sentiments about a divinely-given destination which guarantees survival, and caught these sentiments in a few forceful lines:

And with this I want to make a final appeal to you. It is that we should enter the future full of courage and faith with the eye raised on High, to Him who planted us here with a destination. Let us believe that we are here to survive and let us be ready, with all the power of our hearts, with all the power of our understanding, with all the power of our body, with all we own, to sacrifice what South Africa asks (1963:380; my translation - JJV).

At times he did speak about the humane treatment of black people, but he did not explicitly state the question what for example "being created in the image of God" may have meant for black people in their relationship with white people. I could find no reference in his many published speeches to Christian justice and its meaning for the political arena. Faith, and the belief in a destination given by God himself, too easily becomes a sanctioning and justification of what he and his followers were doing and planning. The self-critical question whether these actions were in fact in line with the Biblical idea of justice and love, does not seem to have been posed by him.

For all practical purposes, Verwoerd was a rationalist. Faith for him, was something separate, a backing from a divine sponsor, who was not supposed to interfere with the editorial policy of the Verwoerdian newspaper. And sentiments had to be suppressed in favour of rational planning for that supposed divinely-given destination. He was very near to a kind of pietism, in which religion empowers the individual, but remains distant from the content of the individual's secular actions. This may have been why he underestimated the emotions working in the country so much. From early on, his discursive framework allowed him to follow a path of rationalist ideologisation - he simply trusted in the combinatory logic of a few inherited axioms (elaborated in the discussion below):

- that whites and the blacks were not on the same level being too far apart to really get together;

- even if those differences could be overcome, then in any case the "volk" was the highest ideal to strive and struggle for, and an ideal which would inevitably be realised;

- everyone who did not serve his own "volk", was a traitor;

- the "volk's" government could only be in the form of a republic; 
H.F. Verwoerd: Foundotional ospects of his thought

- a rational approach on the basis of the previous axioms was the only approach to follow.

\section{The ideal of one "people", one state}

\subsection{Verwoerd's early defence of the National Party (1948)}

In 1948, shortly after the National Party came to power, Verwoerd in a speech in Senate, defended a letter written by the Minister of Native Affairs, in which it was recognized that apartheid could not lead to full segregation. The Minister had said that there would always be blacks within white areas, and that they were to have their own townships with their own local govemments, and that whites had to be taken out of these areas. Verwoerd quoted extensively from the policy documents of the National Party at the time, in which it was stated that the Party stood for the "Christian guardianship" of the European race over the non-white races. This guardianship intended to grant them the opportunities to develop within their own context according to their own natural ability and capability. A fair and just treatment by the country's administration was guaranteed, but "it takes a decisive stand against any mixing of blood between the white and the non-white races". Verwoerd stated that The Party favoured the political and territorial segregation of the native, as well as a separation of whites from non-whites in general, residentially, and industrially, as far as practically possible (1963:4). Verwoerd stated that the ideal is one people, one country, one state:

The apartheid policy has been described as what one could do according to what one views as ideal. Nobody will deny that for natives as well as for the whites total separation would have been the ideal if it happened that way in history. Should there be a white South Africa, as there is a white England and a white Holland or a white France, and if somewhere a native state for natives existed, and if this white state could develop autonomously, economically or otherwise, like those European states developed on their own, then we would not have had the friction and the troubles which we have today. This would have been the ideal condition if we did not have problems. If the native did not have to cope with the white, if he could manage his own affairs, it would have been ideal for him.

And if this is the case, then it can do no harm to acknowledge it and to say it in this way. It can only do good If you realise that you are faced with a complicated situation, then you must know the direction into which you want to move, clear in your consciousness. It is like this in every area of life - one has to direct his eyes to the stars to see how near one can get to the best, the perfect. Therefore I say: keep in mind what is the best for your country and try to approach this, within the limits which the practice of life gives you (1963:3; my translation - JJV). 
The Party, envisaging a "road to a new South Africa" (ironically) recognised the contribution made by non-whites to the development of welfare in the country, but, "in their own interest" and "in the interests of the most harmonious cooperation with the white race", this ought to have happened with recognition of the social boundaries. The Party wished to control labour in such a way that enough farm labour would be available, keeping non-white traders to those areas where the clients are non-white, licensing traders to sell to their own people, introducing a racial quota system for labour, ensuring a decent life for every worker, regardless of race or colour, but: "There must be minimum wages in trade and industry, with the exception of agriculture, for whites, coloureds and natives, whereby the responsible and leading position of the white race and the difference in standards of living among the different groups of non-whites, ought to be kept in mind". And further: "Taking into account the necessity to ensure also in the rural areas for each worker a decent and humanly dignified living, the labour problems in agriculture ... must be placed in a different category" (1963:5-6 - my translation - JJV).

In this quote, the expression, "humanly dignified" occurs in the context of a discussion of minimum wages, showing a vague sensitivity for the needs of the whole population (though fragmented according to ethnic groupings). But the words are not in line with those of Verwoerd - he was quoting from the policy documents of his Party. While the document proceeds to propagate segregation combined with a quota system for black labour "in order to prevent exploitation of one race by another", Verwoerd, in his defence of it, interpreted the document more one-sidedly: black labour would be available; groups would be protected against one another; there would be a dignified wage for the white worker. One could deduce from this that Verwoerd had a vague hierarchical sense of human relationships, in terms of a racial hierarchy, which did not leave much room for concern about the dignity of those perceived to be lower in rank. He had already hierarchised the races for economic purposes in his proposals about employment distribution regarding the poor whites question after the depression (1934: 31). And from the same document he quotes the expression: "maintaining of the white race as supreme task" and

The Party believes that a decisive policy of apartheid between the white and the non-white race groups and the application of the apartheid principle also regarding the non-white groups is the only foundation on which the character and the future of every race can be protected and safeguarded to develop according to own national character, ability and calling. ... In their own areas the non-white race groups will have full opportunity for development in every area, and they will be able to develop their own institutions and social services, through which the powers of progressive non-whites will be used for own nation building ( $1963: 7$; my translation - JJV).

This was the other side of the coin. Practical plans may not have been available at the time, but the policy was there, a product of party thinking, and not simply 
H.F. Verwoerd: Foundational aspects of his thought

of Verwoerd's making. He distinctly denied that this is an oppressive policy, although his interpretation of it seems to have been more discriminatory than the document itself intended to be.

Verwoerd, following the Party document, envisaged residential separation, own local governments for blacks in white areas (which he contended, was much more than the three million Italians who went to France annually could get); no political power for blacks in white areas (where they will be considered "visitors"), neither for whites in black areas.

"The detribalised native must be frozen" - he quoted from the same document This, he argued, did not mean that no black would be able to move into white areas, but only that those who had full residential permission would be admitted An effective in- and outflux control policy had to be implemented. This was "reasonable" according to him. Importantly, the residential and land separation was directly connected with maintaining a bond with the tribe.

The Party at this stage envisaged leading the native to construct his own social, health, and welfare services in the reservations - his own powers would have to be used for that. ("He" is part of the Verwoerdian discourse!) The idea was to start from below, with a local government, into which the tribal headmen would be incorporated, and the "developed native" would have the opportunity to make himself available for "own people's service" ("eie volksdiens") - which could develop into higher forms of government for the reservations:

Two points must be clearly understood. The native who is going to have his residential areas in, or rather near, the cities, and who receives in those areas a high degree of self-governance, will not be able to go further in the white area than local government. If his ambition is in the direction of full citizenship, he must go back to areas which are his. If for the sake of his own selfish interests, for example for his own economic interests, he wants to be in the native residential areas within white areas, then the maximum management in which he can participate, will be the local government. This gives him even more than that Italian can have in France (1963:10; my translation - JJV).

In a reaction to the report of the Fagan Commission at the time, as well as the criticism of it by some academics from Stellenbosch University, Verwoerd carefully noted that the Fagan Report tended to ascribe differences between racial groups to differences in social practice and education; and that it did not allow for a basis in race biology - which, for him, implied the assumption that these differences would finally disappear and that equal treatment would have to follow. Unfortunately, he did not pursue this issue further, and I have not found clear references to it elsewhere, so that we remain in the dark as to his views on the relationship between ethnicity and race. Even though he seems to have avoided to refer to a biological base for the separation, and the separation was (more and more) supposed to have taken place on ethnic (cultural) grounds (and 
therefore executed along tribal lines), the blunt refusal to allow blacks equal treatment with whites in common areas, as well as the refusal of equal rights for coloureds who were culturally "white", indicate a definite, though hidden, racial basis to the Party's thinking about matters of ethnicity.

Verwoerd's judgement of the situation in the "old" (pre-1948) South Africa, brought about by the laissez-faire policies of the previous government - still with reference to the Party program - reads as follows:

What is the present situation? White and non-white are mixedly spread over the width of South-Africa; white and non-white are mixed in trams and on trains; white and non-white are becoming mixed in hotels and in restaurants; are more and more occupying theatres and streets together. Natives are destroying the reserves; they are searching for learning which they do not use in the service of their own nation ("volk"), but which they use to step over the boundaries of whitehood, to become traitors to their own nation by leaving their own nation. This is the image which you get; this is the conditions which you find today. Nobody can deny it. ... Natives ... are busy looking for learning which they do not use in the service of their people ("volk"), but which they use to walk over the borderline of whiteness, to become traitors to their own people ("volk") by deserting their own people ("volk") (1963:12; my translation - JJV).

We must note the discourse used. In the previous quote Verwoerd characterised it as "selfishness" not to serve one's own people, and to prefer to live in a white land. Relinquishing contact with your own people to live in a mixed society, was however, an even more serious matter: he did not hesitate to describe it as "treason" or "desertion". Surprisingly, since the Afrikanervolk with whom Verwoerd identified, is the product of people who left their own people to emigrate to Africa, where they mixed by intermarrying (Verwoerd himself was born in the Netherlands, from where his parents emigrated to Africa). The concepts land, tribe, headmen, self-government, are all here in another's extension. For Verwoerd the alternative to total segregation was the equalisation of all, which would mean black dominance over white - there was no middle way.

Rather than equalisation in a multiracial society, the Party wanted the reserves to be the true fatherlands (in the sense of the Latin: patria) of the natives. The better services had to be given to them there, and the natives living in the reserves had to be accorded real status. Verwoerd was thinking of a dignifying process, correlating status with the measure of one's integration into the affairs of one's mother country and one's ethnic bond. But outside this bond, the according of status was not to be allowed.

Whites in control of white areas, blacks in control of black areas - that was the policy. Over against opposition policy, Verwoerd argued that to keep natives in white areas and allow them to gain learning and limited voting rights there, 
would mean that they could not be blamed if they wanted even more, which finally would tip the balance in their favour. He did seem to have sensed that one's involvement in a specific context did after some time at least, constitute certain rights, and the acquisition of such rights, he believed, would create friction between ethnic groups. There was another possibility, which his party wanted to work for:

And now a picture of the other alternative. Firstly, we want to make the reserves the national home for the different tribal groups. The brains and understanding bom from them can move there, from there those who are looking for education can be drawn, for whom the opportunities will be there. Those who live in the cities of the whites, will have their local rights there. In the transport facilities separation must come, so that even on the white stations the mixing has to become minimal. The main aim is everywhere the removal of friction. Regarding the cities the reserves will play a role independently of the development there, namely one will have to try to gradually draw more and more from the cities there from those who are looking for better opportunities (1963:14; my translation - JJV).

The motive of removing friction remained in Verwoerd's thought. The National Party believed, and so did he, that it is impossible to have different ethnic groups on the same piece of land living in peace. He reminded parliament that in different countries of the world at the time (like Russia and Palestine), where different ethnic groups were trying to occupy all of the country, this was leading to war. South African whites, on the contrary, were working for peaceful coexistence, being prepared to give the blacks a part of the country.

The Opposition, he said, was asking whether justice or injustice was being done to the blacks. Having argued that government policy was not oppressive, he preferred to ask whether justice or injustice was being done to the whites, for it was not the blacks who were threatened, but the whites. In the discourse of the National Party, at least, justice was a question of group membership. Considering it treason to emigrate from one's ethnic bond, Verwoerd was focused on sustaining the ethnic group, in this case the Afrikaner and the English-speaking whites. Thus justice became closely associated with the protection of ethnic identity.

These were Verwoerd's arguments at the time of the National Party's ascendancy to power in 1948. Verwoerd's speech in Senate shows a clever defence of the Party line, quoting extensively from Party documents. The principles stated above, were not the original thinking of Verwoerd alone, but of the National Party. Of course he contributed considerably to policy thinking, having been the editor of one of the Party's newspapers for many years.

Verwoerd, having spent a part of his childhood in the missionary fields in Zimbabwe, probably imbibed Afrikaner nationalism during his student years at 
Stellenbosch University, and also supported and propagated it as student leader in the 1920's, as Froneman (1995:50 ff.) clearly showed. This Nationalism did imply racial separation (which had been practised in the Dutch Reformed Church from the 1850 's). The idea of racial separation in a sense preceded, but also developed parallel to the people's ideal ("volksideaal") of the Afrikaners. So many white leaders, both Afrikaans and English, publicly expressed their support for racial segregation in the first decade after the establishment of the Union of South Africa in 1910, that one can readily assume that a wide consensus about this existed at least among the elite (cf. Pretorius, 1991:4)

- General Herzog, Afrikaner, later Prime Minister (1913) in a letter to FW Bell: 'Ever since 1903 I have advocated segregation as the only permanent solution to the problem'. Talking to the Afrikaners (1913): 'Let us not take the whole of the Union for ourselves, but let us sacrifice a part to the natives ... Whites and blacks must be separated and each must exist on its own'.

- H Sampson, later a cabinet minister (1913), addressing parliament: 'The native could only hope to govern himself and make his own laws in future by separating from the whites'

- Patrick Duncan, political leader (1913), addressing parliament: 'Everyone would agree ... that it is in the best interests of Europeans and natives that points of social contact should be reduced to the least possible area'.

- General Botha, Afrikaner (later rejected), Prime Minister (1912): 'Separation is the only good for the native'.

- General J.C. Smuts, Afrikaner (later rejected), Prime Minister and the philosopher of 'Holism', addressing a banquet of the War Cabinet in London (1917): 'We have realised that political ideas which apply to our white civilisation largely do not apply to the administration of native affairs. To apply the same institutions on an equal basis to white and black alike, do not lead to the best results and so a practice has grown up in South Africa of creating parallel institutions - giving the natives their own separate institutions. ... They are different, not only in colour, but in mind and political capacity, and their political institutions should be different, while always proceeding on the basis of self-government ... Thus in South Africa you will have in the long run large areas cultivated by blacks and governed by blacks, where they will look after themselves in all their forms of living and development, while in the rest of the country you will have your white communities, which will govern themselves separately according to the accepted European principles'.

If we read these views carefully - all preceding Verwoerd's emergence as a student leader, and from sources across the white cultural divide and political spectrum, the convergence of opinion is surprising. All of them favour strict segregation of races, and self-government for the blacks. Smuts' idea of parallel institutions may have been the policies attacked much later, in 1948, by 
Verwoerd in the speech analysed above. But, importantly, these views from well-known men, at least three of them prime ministers at one stage or another, indicate that the general characterisation of Verwoerd as the "architect of apartheid" (cf. for example Kenney, 1980), is an exaggeration. Surely the systematic planring of the execution of the policy of segregation was the product of the social engineer, Verwoerd, but the principles of separation and self-government had been there before Verwoerd came onto the scene. At least one researcher goes as far as claiming that the origins of segregation are to be found in the influential British colonial policies developed in Natal:

... it should be noted that policies and institutions originating in Natal found
favour with later policy makers. The Supreme Chieftainship, demarcation of
reserves, the use of chiefs and the recognition of customary law all became
embedded in 'native' policy. It is a myth that apartheid is the exclusive product
of Afrikaner nationalism: its antecedents are to be found in Natal rather than in
any of the other provinces. A long line of segregationists from Natal did much
to create the climate of opinion in which segregation became acceptable to
white electorates (Welsh, 1971:322).

\subsection{At the dawn of the republic (1960)}

In 1960 Verwoerd, then Prime Minister, began clear steps to move in the direction of a republic. At the same time unrest developed all over the country. Verwoerd addressed a huge crowd of 80000 people on March 26, in which he stated that South Africa was prepared to be friends with all states of the world, especially those in Africa, but that it demanded the right of any free people ("volk") to have its own symbols of independence. As time went by, his political discourse became more idealistic:

Some said tonight's meeting should not have taken place. This was said with regard to the troubles which have taken place in recent times. But troubles we know. It passes. A people's ideal ('volksideaal') never passes. It is realised. And as long as it is not realised, there will be struggle for its fulfilment (1963:351 - my translation - JJV).

Verwoerd's rational style of address, and his insistence on certain ideas, indicate that he was not an emotional demagogue. This was only five days after the notorious shootings at Sharpeville in which 67 protesting blacks died and 186 were wounded on one spot; South Africa experienced unrest, uprising, and dissatisfaction among its black population; and strict measures had been taken by the state to curb the unrest. Verwoerd's language was not emotional play the "people's ideal" represented an ultimate to this man; a driving force in history, which cannot die, and which commands loyalty to the very end.

According to an entry in Mrs. Verwoerd's diary (3 April 1960) his reaction to the unrest was to plan a massive reduction of the blacks in the white areas, and to force manufacturers to border industries. Verwoerd in fact saw himself as a 
saviour of the whites (Afrikaners, in particular), and swore to resign rather than to be an accomplice to the destruction of his people by abandoning the policy (Kenney, 1980:186). The "people's ideal" was his normative ultimate; he simply could not see Sharpeville as a writing on the wall. He was unable to see that the majority of people in the care of his government, did not value their ethnic links in the same way that he did, and that they suffered enough to risk their lives because of his (and his followers') commitment to an ideal that was not theirs. The measure of practicability of the white elite's ideal was already controversial in 1948 (by the National Party's own admission, as we have seen above). Such a blind commitment to a largely abstract ideal, while suffering goes unnoticed and resistance is denigrated as trouble which passes, must be called "ideological" in the negative sense of an idea which is absolutised into a substitute religion.

In the face of liberalism, Verwoerd demanded that the right of the white man of South Africa be acknowledged. This demand was expressed in terms of an "aristocratic" discourse in which a very special status was reserved for the white man. Though recognising the black person's part (as a worker) in the development of the country, he claimed that the heritage of the black man, his health and his learning, and all of civilisation in South Africa, had been carried by the white man. The liberation of Africa was a case in point: in the rest of Africa, he argued, the Africans had proved unable to govern their own countries without the aid of the white man; yet, they were rejecting all white influence. As earlier, he still rejected the liberalist idea that justice is only applicable to individuals and not to nations:

When from time to time there are problems, we have to remember that there is no nation in the world which does not, at one time or another, experience riots or disturbances. ... It is being said that justice is the right of every human being. It is also the right of every people. We believe that the civilised world should take note of this. But if only one thing was possible: if only the world could understand that all of us in South Africa, all groups of the opposition and the government, believe in right and justice, there could have been much more happiness. We all recognise the rights of the black man, and all of us do wish him a prosperous future. We only differ in method. The one sees it in a way in which the white man and his influence will gradually disappear; where the majority is in numbers and not in the strength of character and knowledge. The other sees it in a way which will give everyone full opportunity under his own people ... this is justice for each and everyone (1963:354 - my translation JJV)

Thus the term "human rights" was not absent from Verwoerd's (later) discourse. But, as was said above, he seems to have recognised both justice and rights only in the context of the ethnic community. The connection between rights and ethnic groups is also qualified in terms of advancement, merit, and guardianship (1963:354-356). Verwoerd was concerned with guaranteeing the national life of 
whites while recognising and treating blacks as human beings, albeit of vastly lesser capabilities. The white Christian nation would treat blacks as "fellow human beings", but the world needed to remember that black community life existed by the grace of white civilisation. Verwoerd explicitly recognised the "common basis of humanness" between white and black, but immediately neutralised this by representing whites as none but the saviours of the black race:

We do not intend to get upset by what is being said in all ignorance in the outside world. We plan to do what is right according to our judgement as a Christian nation interacting with human beings and fellow human beings in this country of ours. We realise that there is a common basis of humanness. We also realise what the outside world very often does not: it is that you should not only take the rights of the Bantu, the black man of Africa, into account, but that there is also a white man of Africa to be taken into account. The white man has brought civilisation here and everything which the Bantu today inherits together with us, has been brought into being by the knowledge and the studiousness of the white man. It is true that the black man has participated, mostly as labourer. We recognise the value of that part and seriously want him to be repaid for what he did for the country. But if we had not been here, or did not care for them during these years, they would have perished from hunger or would have murdered one another, and possibly not existed today. The white man of South Africa, the farmer on his farm, the father in his home, cared for the health of his bantu servant. The state cared for his health, as well as for his learning. In many ways the white man was the protector of the black man (1963:354 - my translation - JJV).

How are these words to be judged? Truly the white man brought literacy, health, modern institutions, effective food production, fair techniques for improving the quality of life, and control mechanisms which could neutralise large-scale tribal wars, etceteras, to Africa. But did this merit the occupation of almost all of South Africa's land by whites? Did white weaponry and control always go to the advantage of blacks? Did advantage in cultural possibilities by itself merit a guardianship which denied opportunities and upliftment, and contributed to poverty, illiteracy and lack of skills? Did care for the other, the less advantaged, diminish the human rights of the less advantaged? But then (analogically): should children be refused opportunities to be integrated into society, since they survive on the basis of adult care?

Certainly, in intention, Verwoerd's philosophy was to be "humane" to other human beings. But then from a distance, and not only a geographical but a socially vertical distance for that matter. To imply that black survival on this continent is attributable only to the saving grace of white presence, is to deny that blacks survived for thousands of years in Africa without the intervention of any whites. It is at least one-sided to see only the positive contributions of whites with regard to blacks. Implicitly at work is the Enlightenment view of history, the theme of the divine Western coloniser who mercifully saved the 
barbarian from himself, which comes to expression in Verwoerd's thought. The white man in Africa was Robinson Crusoe saving Friday from cannibalism, introducing him to civilisation and true religion, and acting as his sovereign leader until he could care for himself. A quote from Defoe's Robinson Crusoe may illustrate the spirit of the Western coloniser:

My Island was now peopled, and I thought my self very rich in Subjects; and it was a merry Reflection which I frequently made, How like a King I look'd. First of all, the whole Country was my own meer Property; so that I had an undoubted Right of Dominion. 2dly, My People were perfectly subjected: I was absolute Lord and Law-giver; they all owed their lives to me, and were ready to lay down their Lives, if there had been Occasion of it, for me (1990:241).

The humaneness of Verwoerd was neutralised, and the dignity of the black man removed, because of a deep and inherent colonial arrogance on the white side. The consequence of Verwoerd's words quoted above is that blacks had to be thankful to the whites that they are alive. Verwoerd did not recognise the right to equality in dignity - progress and advantage seems to have lead to inequality in rights. Rights were (in his mind, apparently) at least partly determined by the cultural situation, and given the vertical distance between the two communities, the twain could not meet.

Verwoerd believed to the very end that which he stated from his earliest public appearances (cf. Verwoerd 1934:31-32) - that the interests of the Afrikaner, later the white-nation-in-spe, were also the interests of everybody in the country; the Afrikaner, and the white people in general, was a people caring for the less privileged and less knowledgeable in such a way that it would be to their advantage as well as to its own. This is the basis for the top-down attitude (even arrogance) found in Verwoerd's views on development: the interests of the supposed elite were supposed always to coincide with the interests of all other groups (cf. 1963:363; also Kenney, 1980:29).

In summary: there is something tragic about Verwoerd - he was so convinced of his ideal, that he was totally unable to see that the unrest all over the country was an indication of a thorough dissatisfaction with his policies towards black people.

- He could only see what whites were doing for blacks, and not what they were doing to blacks. Trouble meant no more than part of an ennobling struggle of the people for its own.

- It was impossible for Verwoerd to recognise something deficient in his own idea of justice. Justice, for him, could not be understood outside of the ethnic group, with its racial roots, and within a culture and a basis of (scientific) knowledge. He could not see justice as a supreme norm for the state; he 
subjected justice itself to a higher condition - that of the membership of a free ethnic people.

- It is the conception of a "people" which is foundational and transcendental in this respect. Remarkably, a definition or even a vague circumscription of what a "volk" is, is apparently not to be found in Verwoerd's writings. (At the seventeenth Verwoerd Memorial Lecture (1991), Pretorius, a fervent admirer of Verwoerd, spoke about the "'People' concept of H.F. Verwoerd", but neither definition nor circumscription of the concept "volk" is found in the address.)

\section{Development}

Verwoerd and his fellow nationalists realised that it would not be possible to accommodate all the people in agriculture in the reserves. The policy was therefore more than only one of separation of ethnic groups; it was not the intention to just dump blacks in the reserves to care for themselves. Apartheid was, from the assumption of power by the National Party, a development policy very similar to dualistic policies of development elsewhere in the world (explained below); that is is why it could later be substituted with the term "separate development". (Of course, the majority of black people experienced it as rejection and suppression rather than development.)

\section{4.] Economic development}

Apart from agriculture, therefore, the supposition was that industrial and urban development would have to accommodate large numbers of black people. This, in principle, demands a very strictly planned society - totalitarian in some sense: "You must take care that the building of the nation within its own area will happen in such a way that it will give work and opportunities in all kinds of spheres of life" (Verwoerd, 1963:15).

Verwoerd (in 1950, as Minister of Native Affairs) claimed that the section of the white community which was prepared to share power with blacks in the same parliament, was in any case not prepared to allow for more than communal representation of the whole group of blacks. Fearing that even this would tip the balance of power in favour of blacks, the National Party preferred to give black people power in their own countries (as was amply discussed above). It was a question of allowing unto others that which white people demanded for itself each in control of his own area. But the political aims of the preservation of white rule in the larger part of the country was interwoven with development aims for black people:

They must find a plan which can bring both population groups to full development of their powers and ambitions without it resulting in clashes. The only possible solution is the second alternative: that both accept a development 
separated from one another. This is all that the word 'apartheid' means. Any word can be poisoned by giving false meanings to it ... For whites, the government wants to create all the possible opportunities for development, welfare and people's service ('volksdiens') in his own area; but for the Bantu it also wants to create opportunities for the fulfilment of ambitions and the supplying of services to its own people. This is therefore no policy of oppression, but for the creation of conditions which have never existed for the Bantu, namely that he, taking into account his own languages and traditions and history and different ethnic communities ('volksgemeenskappe'), can experience an own kind of development. This opportunity exists for him as soon as a separation comes between him and the white so that he need not be the imitator and servant of the latter (1963:21-22).

Verwoerd knew all too well that only one third of the blacks were at that stage living in the reserves (another third were on white farms, and the rest in the cities). He also knew that the reserves were unable to carry the burden of their inhabitants, but he was convinced that they could flourish, and be developed so as to be able to care for their own people, since development would transcend agriculture into industrial development, while at the same time an administrative and educational superstructure would emerge, into which large numbers of people could be absorbed. Development in this case, he believed, would take place exactly as in the prosperous countries (1963:23).

Already at this early stage he developed the basic principle of what became known as the border industries policy. Basically it is the dualistic development theory made to fit South African circumstances, assuming that welfare would filter through from nearby white border industries into the black homelands:

Therefore the white industrialist will have to be encouraged to establish industries inside the white areas near such towns and cities. Bantus who work there will live inside their own native areas where their own schools exist, where they have their own traders and govern themselves. The core of the apartheid policy is anyway that in the measure that the white is not needed by the black anymore, the white must withdraw from the biack areas (1963:23; my translation - JJV).

It is noteworthy that the economic aspects of Verwoerd's vision of development were exactly in line with the so-called "dualistic" development theories (cf. Meier, 1989:111 ff.), which were fashionable at that time. The dualistic theories were meant to explain and guide economic development in societies with a sophistication/modernisation gap. They were supposed to apply to economies in which there is a modern capitalist sector, and a traditional sector, and these two sectors function on the basis of very different or even contradictory principles. The traditional sector would usually be unsophisticated, labour intensive, agricultural, with an oversupply of unskilled labour. The modern sector tended to be capital-intensive, industrial, and in need of skilled labour. Different links between the two sectors were constructed: selling of goods from the modern 
sector to the traditional sector; buying of labour and raw materials from the traditional sector by the modern sector (allowing also for disturbances of these links by import/export changes).

A very important assumption determined policy-making in these models: the trickle-through effect. It was assumed that growth (which was almost equated with development) in the modem sector would trickle through to the traditional sector. Policies were therefore aimed at stimulating growth in the modern sector, in the hope that the effects of this would gradually cause development in the traditional sector. Apparently, as policy guidelines, these theories did not have enough success - the trickle-through effect did not produce the expected results, and new models and theories were developed. (Ironically, the neo-classical theories of the 1950's are now gaining a new lease on life, as global society is returning to some very harsh principles of free market capitalism.)

But this was very near to what Verwoerd had in mind. His policy was to stimulate the development of a modern sector (called "border industries") near the borders of the black homelands, believing that labour and goods could then move over the borders between the modern white industrial economy and the rural, agriculturai black community. He also believed that the presence of these border industrial developments would have a trickle-through effect into the homelands, causing development on the other side of the border. In fact, in the long run, he expected enormous development, from an agricultural to an industrial economy, and in its superstructure all the sophistications of a modern civil society. Minimal direct intervention from the white (Western) society was needed - as the developments would take form, white presence would no more be needed in the homelands. Of course the gap between the modern and the traditional sector in the South African setting was (also) a racial and ethnic gap. Dualism here confirmed the racial and ethnic policies of the National Party, and supported the idea of a fully separate development. And, as elsewhere in the world, in the longer run, the trickle-through effect did not deliver the expected results.

Verwoerd acknowledged that the conditions he envisaged for the reserves, would be difficult to realise in practice. He therefore used the concept of "apartheid" in the sense of "separate development" itself as an ultimate, a final normative ideal which had to be realised as far as possible, and against which all plans had to be measured. He could only understand this in terms of supreme ethnic ideals:

For the present leader of the Bantu, co-operation to execute the apartheid policy, as described here, is one of the greatest services which he can deliver to his people ('volk'). Instead of hunting for vague phantorns of the brain, and try to be equal to the white in a scrambled society with confused ideals and inevitable clashes, he can be a man of the people ('volksman') who helps to lead his own people on the road to peace and prosperity. He can help to give an 
opportunity to the children and the learned [members] of his people to find employment or live out their ambitions to the full within their own areas; or where this is not possible, in white areas, to work and serve in own, separate context (1963:25).

\section{2 "Progress"}

Verwoerd conceptualised this development in ethnic terms - by 1955 he had developed a policy framework for community building. Development and progress became one concept - an analysis of the latter highlights some philosophical aspects of his view of development.

Progress was considered possible only in terms of an inherent (organismicallyconceived - like in Rousseau), power to grow, dependent upon the presence of bearers of progress inside a community. In Verwoerd's discourse "progress" is always and only present when the whole of an organic community internalises a change for the better, rather than only a few members realising the change by outwardly learning it (say in school). He did not see any progress in the phenomenon of a few blacks becoming superficially modernised in Westem terms. Progress, for him, meant that a whole community grows into higher functions from the inside, following the leadership of an elite:

Real progress is based on the fact that within a community a satisfactory number of individuals are found to act as bearers of progress, as bearers of the higher social life forms, and that the community as a whole understands their striving and supports them in this. The forming of human material to fulfil these conditions, is therefore a precondition, and therefore education plays such an important role (1954:82).

Significantly in another context (addressing the Transkei Regional Authority), Verwoerd defines apartheid in the same terms. According to Verwoerd "apartheid" thus signifies progress, since it develops a people from within

Apartheid means: 'something of your own'; the other word refers to something even greater, i.c. 'development', which implies 'growth'. A human being should not regress if one undertakes a task. Through the work of one's hands something must come into being. This is creation; and development is growth by what one creates anew in a continuously flowing process. Therefore separate development means the kind of growth which one creates by means of own power and for the sake of yourself and your people (1963:138)

At least as far as the white community is concerned, he believed, like so many eighteenth and nineteenth century thinkers, that progress is inevitable, and that obstacles in fact serve progress. Thus, in his opening speech at the Rand Easter Show (9 April 1960), soon after the Sharpeville massacre, stressing the enormous growth of the Union of South Africa in agriculture, mining, and industry, which was highlighted at this "shopwindow of our progress" and "greatness", he expressed this inevitability in very clear terms: 
Nothing that comes between, and which upsets people so much that they think an end to a phase in our life has arrived, and that there is now regress, ever works out in this way. If we study history, we find that it consists of one crisis after another, but from every crisis greater triumph is born. It is true of a people's ('volk') life, and it is also true of its entrepreneurial spirit. Agriculture had its ... droughts and pests; the industries their depressions ... the mines their difficulties ... but from each [obstacle] greater vitality was born. In the same way not loss, but greater and greater development in every area of South African society will follow upon what we are now experiencing (1963:365).

This inevitability of progress, strengthened and confirmed by crisis, which, for Verwoerd, was also part of the self-imposing historical realisation of the national ideal, echoes the eighteenth century (Rousseau, Kant) and nineteenth century (Comte, Marx) belief in progress. In Verwoerd's speech it is couched in the form of a speech of encouragement in a time of crisis, and one cannot establish direct links to specific sources, yet it expresses the spirit of the tradition about progress. A single quote from Kant (not as precursor of Verwoerd's ethnocentric history), may illustrate how progress was supposed to sustain itself through history according to this tradition:

And, however, limited our view may be to see the secret mechanisms of its setup, this idea may still serve for us as a guideline, to establish an otherwise planless aggregate of human actions as a system. For if we start at Greek history ... if one follows the influence of this on the Roman state system (which swallowed up the Greek system), and the influence of the latter on the barbarians (who, in turn, induced the collapse of the latter), right up to our own times ... we shall discover a regular process of improvement of the state system in our part of the world (which all other established ones will probably also show). As long as one further pays attention only to the civil order and its laws, and to the conditions of state (in as far as both through the good which it implied, for a time served to elevate nations ... but because of the deficiencies inherent in them, made them collapse again - yet in such a way that always a germ of enlightenment remained, which, further developed by every revolution, prepared a further, even higher phase of development), then a guideline will reveal itself ... which will open up a comforting perspective on the future (Kant, 1975:48-9; my translation - JJV)

Instead of the idealised "volk", Kant represented the state as the concrete expression of progress. His view of history is one of revolutionary progress in an organismic (teleclogical sense); it is through the catastrophes of one state that a new, higher political and cultural order is bom. But the similarities between Verwoerd's views and those of Kant are clear. Verwoerd did not express his view of history in revolutionary terms, and he substituted "volk" for state. Structurally, though, his sense of progress is very much the same as that of Kant: revolutions of state become crises of the "people;" organic growth from state to state in one civilisation (the Western civilisation) becomes organic growth in one nation (note the education policies of Verwoerd, discussed 
below). The organic unity of the nation state was already prefigured in JeanJacques Rousseau's views (cf. Venter, 1996:184 ff.) - views carried in the tradition of republicanism in the Afrikaner mind since the Batavian Republic at the Cape, before the British annexation in 1806.

Verwoerd also, at the same occasion, welcomed the international exhibits, in terms of the idea that progress is promoted by competition, but warned the competitors that it would have to be a friendly competition, for no nation would reach great heights if it trampled on another's corpse, and that "we" would fight for our existence if any nation was thinking of killing "us" (1963:369).

He firmly believed that prosperity in South Africa depended upon the final solution of the racial question in such a way that the blacks would experience happiness and prosperity, while the whites would be able to govern themselves. This final solution, he said, was the policy of good neighbourliness (which of course implied creating the neighbouring states) - not a new policy at all, but one which existed throughout the history of South Africa (implying, I think, that the history of the Afrikaner's interaction with other groups since 1652 has been the only history of South Africa worth considering). For him, of prime importance at this stage, on the eve of the advent of the supreme ideal, the republic, was the unification of the Afrikaner and the English-speaking whites into one people ("volk") with two languages, under one set of national symbols.

Thus the inevitability of progress coincided with (the inevitability of) separate development. Preserving the identity of whites in a separate nation state was considered a sine qua non for the development of the black peoples; separation of the black peoples to develop on their own under the leadership of their white neighbours was also a sine qua non. But under the guidance of the idea of progress, nothing could in the ultimate sense go wrong - there can be no regress. This view of history - which carried the nineteenth century scientistic utopias such as Saint Simonianism and Communism (cf. Von Hayek, 1952), has in itself an ideologically blinding effect, for it prejudices the interpretation of crises: crises cannot serve efficiently as warnings of an approaching cul-de-sac, for they are only the birth pangs of further progress.

\subsection{Education as development}

In any modernising society formal education is part of the development process. For it is through education that one is introduced to modern culture, its technological know-how, its sophisticated ways of communication (which is a sine qua non to remain in contact with a society which changes at a high rate). Verwoerd, as minister of Bantu education, realised this developmental aspect of education, but, as is to be expected, could only approach education from the perspective of serving one's own people. 
According to Verwoerd the basic principle of curriculum construction in schools would therefore be that of development by internal growth - a principle understood by oppositional blacks to have meant denying them access to modern professions, and keeping them in an inferior position. This reaction was not totally off the mark. Verwoerd assumed - and even this was a tradition coming from the beginning of the nineteenth century - that whites, being advanced, were the guardians of the blacks, and therefore had the right to decide what would be good for the latter - what would count as absorbable progress for them. Although softening the denigrating discourse of the time, his idea of development did not allow for preparing blacks to be integrated into white society, and curricula had to be set according to the needs of the different black communities, as he understood those needs (which actually were the needs of the apartheid state):

The curriculum (to a certain extent) and the practice of teaching, ignoring the policy of segregation or apartheid, could not offer preparation for service within the black community. By simply blindly producing pupils formed on a European mould, the vain expectation was created that they, in spite of the said national policy, would still be able to fill posts in the white community. This is what is meant by the unhealthy creation of white collar ideals and the causing of widespread frustration among the so-called learned natives (1954:7; my translation - JJV).

Verwoerd therefore took full control of education for blacks - church schools and training centres were taken over by the state. The training of teachers had to follow the same principle as that of the pupils; they had to be prepared for the demands of the black community, as well as for the demands of economic life in South Africa:

The bantu teacher has to be involved as active factor in the development process of the bantu community, in order to serve and build this community. He must not learn to feel himself above his community, so that he will want to be integrated into the white social life and become frustrated and rebellious if it does not happen, so that he will make his community dissatisfied because of such wrongly directed ambitions foreign to his people ('volksvreemd') (1954:15). Previous policies and practices did not bring native teachers to accept that the circumstances of their community had to be the point of departure for teaching; they rather wanted to show off the feathers of their English education, actually preparing pupils for a life outside their community and for posts which did not exist; creating an elite class who thinks that they are elevated above their own community (1954:17; my translation - JJV).

The demands for integration into the black community and for preparation for the economic circumstances, among others, implied that black children on white farms would be kept on the farms (given improved education), and that the education could improve their circumstances on the farms, since they would then be better educated and eligible for better wages. In the experience of the 
black community this simply meant inferior education for the sake of economic exploitation.

Verwoerd was a technocratic planner, who almost endlessly repeated the same ideas applied to different contexts. The whole of the black community, as well as the whole of the white community, was subject to his great development plan - a possible remnant from his early positivist days. The plan was to solve all frustrations, and had to provide the maximum advantage for the greatest number:

It is my department's policy that education must be rooted with both feet in the Native lands and in the Native spirit and community. Bantu education must be able to find complete fulfilment, and its true service it will have to execute here. The Bantu must be guided to serve his community in all respects. There is for him, above the level of certain forms of work, no place in the white community. Within his community all doors are open. It is therefore of no advantage to him to receive a training which aims at integration into the white community, while he will not be able to be accommodated there. Up to now he has been subjected to a school system which exactly seduces him away from his own community and factually misleads him by showing him the green pastures of the white but does not allow him to graze there. This attitude is not only uneconomical for money is spent on education which serves no purpose but is even dishonest to continue with. The effect of this in the Bantu community we find is the much debated frustration of trained Natives who can find no circle of employment which is acceptable to them. It is simply clear that unplanned education creates lots of problems, distupts the community life of the Bantu, and endangers the community life of the white man (1954:24; my translation - JJV)

Summarising: Verwoerd's whole conception of development was constructed around a few basic ideas. Firstly, he harboured the belief that there was a vast gap between white advancement and black backwardness, which implied a guardianship of white over black. This was fused, secondly, with the idea that development can only take place within the boundaries of the ethnic group, as a unity which has its own organic growth. In fact, Verwoerd's recognition of a "common humanness" was not so far removed from the ubuntu-axiom, "a human being is a human being through other human beings", but then the "other human beings" have been specified by him as the "people". And, thirdly, history, for him, implied inevitable progress; all obstacles and conflict only promotes progress; this blinded him for all suffering of those subjected to his policies (for their objections were submerged in factors promoting progress)

\section{Conclusion}

This article is a journey in search of some ultimate concepts which governed Verwoerd's thought, which determined his values and his view of human life. 
The rationalist, Verwoerd, departed from a limited set of axioms, which he consistently applied to the South African situation. Most of his basic ideas can be seen as part of the Western, colonial, and Afrikaner heritage. He became the totalitarian technocratic planner who transformed these basic ideas into legal and policy plans for implementation. Neither religious criticism of his idea of justice, nor the strong sentiments of those involved, could deter him from the road he believed rational, and his policies were executed almost as mathematical deductions from the few basic tenets which he inherited. Though he was a Christian who grew up in the mission field, and who expressed his belief in God and Christ openly, he did not allow his Christian beliefs to criticise his political ideology.

As far as his points of departure are concerned, he was not an original thinker. He inherited the ideal of a "volksrepubliek" from the Afrikaner Enlightenment heritage (with some idealistic overtones). He believed in the organic unity of the "people", which again goes back to the Afrikaner's interpretation of the Enlightenment heritage. This idea was always associated with totalitarianism, since it attempts to encompass all aspects of human life within the confines of the "volk" (cf. Venter, 1997:43 ff), and it is not surprising that Verwoerd's government took charge of all aspects of life (marriage, economy, education).

He believed strongly in the ideal of one people, one state, with its own government - a principle he inherited from the white leadership of his student days But this ideal was expanded to include the totality of human life: development and education could only take place within the confines of one's own people, and therefore in the homeland of the people.

He shared the colonial belief in the backwardness of the traditional cultures, and could only think of them in terms of white guardianship, organic development within own culture, and inevitable progress - all of which are Western ideas rooted in the eighteenth and nineteenth century. His view of history in terms of inevitable progress, and his identification of apartheid with progress, blinded him for the historical waming signs that his policies, in spite of his intentions to be "humane" and to protect the rights of every people, was causing suffering and serious resistance

Lastly, his development theory had much in common with dualistic development theories which emerged more or less at the same time as his border industries policy - both visions shared the idea of a trickle-through effect going from the modern to the traditional sector (with Verwoerd's sectors following the racial divide). This vision of development supported an exclusivist idea of development, which in South Africa coincided with racial exclusion from the mainstream of economic, political, and educational development. 
Verwoerd's fairly consistent logical application of his few principles showed one clear inconsistency - the idea that Afrikaans- and English-speaking whites could become one "volk" with two languages. This can be interpreted as a manifestation of the racism hidden behind the ethnic colouring of the policy: was the idea of a white "volk" not part of preserving white hegemony?

In this article, I have attempted to highlight the foundational aspects of Verwoerd's way of thinking, as he himself expressed it. In doing so, and even in criticising it, the idea was not to shove responsibility to one person. It was rather to highlight a few foundational ideas by which all who have been supporters of the policy of separate development, have been guided. These ideas found expression in Verwoerd's formulations, but the responsibility for their implementation and their consequences, lies with all those who have admired and supported him.

\section{Bibliography}

DEFOE, D. 1990 The life and strange surprising adventures of Robinson Crusoe, of York, Mariner. Ed. by J. Crowley. Oxford OUP (The World's Classics.)

FRONEMAN, JD 1995. Die kommunikasie van Afrikanernasionalisme deur Stellenbosse studente, 1902-1948 Potchefstroom : PU vir CHO. (Unpublished Ph D. dissertation.)

HABERMAS, J 1980. Towards a Rational Society. Student Protest, Science, Politics Tr. by J J Shapiro London: Heinemann

KANT, I. 1975 Idee zu einer allgemeinen Geschichte in Weltburgerlichen Absicht. (In Kant, I. Werke in Zehn Banden. Bd. 9 Darmstadt : WBG.)

KENNEY, H 1980. Architect of Apartheid. H.F Verwoerd, an Appraisal. Johannesburg Jonathan Ball.

MEIER, G M. 1989 Leading Issues in Economic Development NY/Oxford : OUP

PRETORIUS, P J V E. 1991. Volkerebegrip van H.F. Verwoerd. Sewentiende H.F. Verwoerd Gedenklesing. Pretoria : SABRA

ROETS, J 1996. Art and Worldview: A Philosophical Study of the Enlightenment Potchefstroom : PU for CHE.

VENTER, J.J. 1991. Inleiding (In Kant, I Samelewing en vooruitgang; drie traktate Tr by J J. Venter Potchefstroom : PU vir CHO. p. 1-15.)

VENTER, J J. 1996. World Picture, Individual, Society Neohelicon. Acta Comparationis Litteranum Universarum, 23(1): 175-200.

VENTER, J.J. 1997. Mechanistic Individualism versus Organismic Totalitarianism Ulitimate reality and meaning; Interdisciplinary studies in the philosophy of understanding, 20:4160

VERWOFRD, H.F 1925. Die afstomping van gemoedsaandoeninge. Kaapstad : Nasionale Pers

VERWOERD, HF 1934 Die bestryding van armoede en die herorganisasie van welvaartswerk Verslag van die Volkskongres oor die armblankevraagstuk gehou te Kimberley, 2 tot 5 Okt. 1934 Red P du Toit. Kaapstad : Nasionale Pers p 30-40

VERWOERD, H F 1963. Verwoerd aan die woord Toesprake 1948-1962 Red AN. Pelzer Pretoria : Afrikaanse Pers Boekhandel

VERWOERD, H.F. 1954 Bantoe-onderwys: Beleidsbepaling vir die onmiddelike toekoms. Verklaring deur dr H.F. Verwoerd, Minister van Naturellesake, in die Senaat van die Parlement van die Unie van Suid-Afrika, 7 Junie 1954 Pretoria : Staatsdrukker. 


\section{H.F. Verwoerd: Foundotional aspects of his thought}

VERWOERD, H.F. 1959. Die keuse: Rasvermengde vaderland of blanke Suid-Afrika? Toespraak van sy edele dr. H.F. Verwoerd ... i.v.m. die Wetsontwerp op die Bevordering van Bantoe-Selfbestuur, Volksraad, 20 Mei 1959. Bloemfontein : Nasionale Party Inligtingsdiens.

VON HAYEK, F A 1952. The Counter-Revolution of Science. Glencoe, Ill. : Free Press

WELSH, D. 1971. The Roots of Segregation. Native Policy in Colonial Natal, 1845-1910. Cape Town/London/New York : OUP 